\title{
The removal performance of nitrates in the novel 3D-BERS with GAC and diversity of immobilized microbial communities treating nitrate-polluted water: Effects of $\mathrm{pH}$ and $\mathrm{COD} / \mathrm{NO}_{3}{ }^{-}-\mathrm{N}$ ratio
}

\author{
Mahdi Hassan ${ }^{1,2,3}$, Guangcan Zhu ${ }^{1,2^{\dagger}}$, Zhonglian Yang ${ }^{1,2}$, Yongze Lu $^{1,2}$, Huang Shan ${ }^{1,2}$, \\ Yan Yang ${ }^{1,2}$, Liying Gong ${ }^{1}$ \\ ${ }^{1}$ School of Energy and Environment, Southeast University, Nanjing 210096, Jiangsu, China \\ ${ }^{2}$ State key Laboratory of Environmental Medicine Engineering of the Ministry of Education, Southeast University, Nanjing 210096, Jiangsu, China \\ ${ }^{3}$ Energy and Environment Engineering Department, Quaid-e-Awam University of Engineering, Science and Technology, SBA, Pakistan
}

\begin{abstract}
In this work, a three-dimensional bioelectrochemical reactor system (3D-BERs) with granular activated carbon (GAC) was utilized to study the feasibility of simultaneous removal of nitrates by autotrophic-heterotrophic denitrification process under different $\mathrm{pH}$ levels. In this present study, it was found that when the influent $\mathrm{COD} / \mathrm{NO}_{3}^{-}-\mathrm{N}$ ratio ranged between 1.5 and 3.5, both autotrophic and heterotrophic denitrifying microorganisms played an important role in denitrification. The experimental results demonstrated that the highest removal efficiency of nitrates under the optimum $\mathrm{COD} / \mathrm{NO}_{3}{ }^{-} \mathrm{N}$ ratio of $1.5(98.62 \%)$ was achieved with an initial $\mathrm{pH}$ of $7.5 \pm 0.4$. Likewise, when the $\mathrm{COD} / \mathrm{NO}_{3}{ }^{-} \mathrm{N}$ ratio of 3.5 , the nitrates removal efficiency $(81.12 \%)$ was achieved with an initial $\mathrm{pH}$ of $8.2 \pm 0.3$, respectively. Batch denitrification processes followed zero-order kinetics at various $\mathrm{NO}_{3}^{-}-\mathrm{N}$ concentrations obtained. The bacterial community structure and relative abundance of bacteria changed at the level of genes and the phylum of immobilized GAC particles. Moreover, the diversity of bacterial composition enhanced the removal of $\mathrm{NO}_{3}^{-}-\mathrm{N}$ at the inner surface (IS), and bottom surface (BS) of immobilized GAC carriers were Gammaproteobacteria, Bacilli, Proteobacteria, and Thauera. In general, this technique is more effective for enhancing the denitrification process in the 3D-BER system.
\end{abstract}

Keywords: Bacterial Community, Denitrification, Immobilized Granular activated carbon, Kinetic Models, 3D-BER system

\section{Introduction}

The coexistence of various pollutants is a ubiquitous feature of natural water, contaminated groundwater, and municipal wastewater, with commonly occurring substances such as heavy metals and nitrate, widely investigated in environmental research [1, 2]. Nitrates are considered one of the most hazardous contaminants worldwide [3, 4]. Moreover, to the extremely high amount of nitrogen being continuously discharged into the environment, excess nitrate was also introduced into the aquatic-ecosystems [5, 6]. Nitrates can react with secondary and tertiary amines and methemoglobin to form carcinogenic nitrosamines in an infant. In spite of the World Health Organization (WHO) guideline value of $10 \mathrm{mg} / \mathrm{L}$ for human consumption, the concentration of nitrates in the water body in many regions is up to $400-500 \mathrm{mg} / \mathrm{L}$ [7]. Thus, it is urgent to develop an efficient technique for the removal of nitrates [8]. Nitrogen-containing compounds discharge from different wastewater treatment plants (WWTPs) may seriously threaten surface and groundwater, causing eutrophication of water bodies and severe impacts on human health [9]. To prevent severe water resource contamination by nitrogen pollution, the Chinese standards are set for pollutant discharge from municipal wastewater treatment
cC (5) This is an Open Access article distributed under the terms of the Creative Commons Attribution Non-Commercial License (http://creativecommons.org/licenses/by-nc/3.0/) which permits unrestricted non-commercial use, distribution, and reproduction in any medium, provided the original work is properly cited.

Copyright (C) 2022 Korean Society of Environmental Engineers
Received September 20, 2020 Accepted February 15, 2021

${ }^{\dagger}$ Corresponding author

E-mail: gc-zhu@seu.edu.cn

Tel: +86-18912966396

ORCID: 0000-0001-5430-6441 
plants (2002-GB18918) [10]. Therefore, some treatment technologies need to be developed to further reduce nitrate residues in discharge, as strict environmental requirements have been implemented on nutrient discharge into receiving waters [11, 12]. The most common traditional methods for nitrate removal include adsorption [13], reverse osmosis [14], physicochemical [2], electrochemical [15], ion-exchange process [16], and biological treatment methods [17]. There are several limitations for physical or chemical approaches, i.e., high-level energy constraints, secondary pollution, and complex friable condition $[10,13,18]$. Among these various methods, the biological process is usually less costly in terms of maintenance and operational costs compared to physical and chemical processes [17]. Biological methods are efficient and cost-effective nitrate removal process that has been of increasing research interest [7].

Meanwhile, heterotrophic-autotrophic denitrification (H-AD) is used in biological processes in which nitrates can be reduced entirely to nitrogen gas without producing nitrogen residues, demonstrating the advantages of economic efficiency and environmental friendliness [2, 19]. Bacterial immobilization technology has been widely used in wastewater containing a high amount of nitrates, organic matter, and toxic chemicals [20,21], which has the advantages of high biological density, strong anti-toxicity, and fast start-up processes [22]. In addition, the contribution in the GAC between heterotroph and autotrophs denitrifies increased the improved the removal efficiency of nitrogen [2, 23].

For the supporting GAC, carriers play an important role in the bacterial immobilization system [21, 23]. The GAC is an organic, non-porous polymer fixing material with a high mechanical strength level, extreme adaptability to the condition. It has excellent performance, as reported by a previous study [14]. While, in the 3D-BERs with GAC as a fixed system to support mixed bacteria in the biological denitrification process, as they can provide a gradient concentration of dissolved oxygen and ample active area for the growth of high-density complex flora, which includes bacteria that reduce nitrate and nitrite [24]. However, little literature was available on the applicability of GAC-based bacterial immobilization techniques for treating nitrate-polluted water [25, 26]. The biofilm bacterial diversity on the GAC carrier must be examined in a situation with a low concentration of nitrates [27]. While in the denitrification process, several intermediates are formed during the conversion process from nitrogen oxide to gaseous $\mathrm{N}_{2}$ [17]. Accumulation of a certain amount of nitrate-nitrogen under various conditions would seriously affect the removal efficiency of total nitrogen as consistent with the previous study [2], and has the close attention to the effects of carbon sources [28] and $\mathrm{pH}$ on nitrite accumulation [15]. However, little literature on the effects of an initial nitrate ratio to nitrogen on anaerobic denitrification, including denitrifying enzyme activity of and rich denitrification genes, has been discussed $[8,18]$. Traditional denitrification processes depend on the operation of four primary denitrifying enzymes, including respiratory nitrate reductase has shown: $\mathrm{NO}_{3}{ }^{-} \rightarrow \mathrm{NO} \rightarrow \mathrm{N}_{2} \mathrm{O} \rightarrow \mathrm{N}_{2}$.

Therefore, many studies indicated that nitrate effects on the denitrification activity depended on existing denitrifying enzymes [29]. The heterotrophic process needs organic carbon to promote cell growth and serve as electron donors during the denitrification $[17,30]$. Dong et al. [14] reported that the inhibitory effect on the denitrification process is due to a related inhibition of the denitrification gene abundance that causes $\mathrm{N}_{2} \mathrm{O}$ accumulation. However, few studies recognised that the impact of the initial nitrate to nitrite ratio on nitrate removal and the nitrite reduction efficiency of the microbial immobilization system using GAC (MIS-GAC) immobilized microorganisms to treat wastewater [31]. As most denitrifying microorganisms are heterotrophic, the addition of specific organic carbon source can enhance the nitrate removal, and organic carbon discharge is usually limited [9, 32]. The 3D-BER system only requires an organic carbon source to accumulate and enhance the removal of nitrogen using different $\mathrm{COD} / \mathrm{NO}_{3}{ }^{-}-\mathrm{N}$ ratios. The 3D-BER technology is still in its early development stage, with only a few denitrification studies reported in the literature [5, 7, 33]. The 3D-BERs actually combined the biofilm and electrochemical system, taking the benefits of these two treatment processes. In the 3D-BERs, particles such as Iron, Sulfur and GAC are occupied between cathode and anode, not only serving as the third bipolar electrode also providing colossal surface area for attachment and bacterial growth [31, 34]

In this research work, a novel 3D-BER system performance on the microbial diversity of the immobilized GAC biofilm carriers with non-porous polymer for treating nitrate-polluted by heterotrophic-autotrophic denitrification. The specific objectives of the present study were to (1) extensively analyse the effect of the low inlet $\mathrm{COD} / \mathrm{NO}_{3}{ }^{-}-\mathrm{N}$ concentration ratio on nitrogen removal and $\mathrm{pH}$ were optimized in batch experiments; (2) to investigate the appropriate influent rate of $\mathrm{COD} / \mathrm{NO}_{3}^{-}-\mathrm{N}$ range for nitrogen removal and the effect on nitrate to nitrite concentration for the nitrate reduction and nitrite accumulation; and (3) identify the different concentrations of nitrates for the removal of nitrogen were compared by employing kinetic fitting models. Moreover, the denitrification process was studied, and the bacterial community structure on the inner and bottom surfaces of the GAC carrier were measured. These results may provide valuable information to design cost-effective denitrification processes for the extraction of nitrates and to enhance denitrification for solving many problems of municipal wastewater treatment.

\section{Materials and Methods}

\subsection{Reactor Configuration of the 3D-BER System}

As shown in Fig. 1 was the schematic diagram of the three-dimensional bioelectrochemical reactor system (3D-BERs) used in this study to evaluate the diversity of immobilized bacterial communities and nitrates removal by simultaneous heterotrophic-autotrophic denitrification $(\mathrm{H}-\mathrm{AD})$ in the treatment of nitrate-polluted water. The reactor was made of plexiglass cylindrical with a diameter of $10 \mathrm{~cm}$, a height of $20 \mathrm{~cm}$, a total volume of $1.2 \mathrm{~L}$, and a working volume of $0.785 \mathrm{~L}$. The cathode consisting of eight graphite rods (with a height of $20 \mathrm{~cm}$ and diameter of $0.8 \mathrm{~cm}$ ) were placed around the periphery of the reactor, while the one graphite rod (with a height of $20 \mathrm{~cm}$ and diameter $1.5 \mathrm{~cm}$ ), as an anode was fixed in the centre of the reactor and were connected using insulated electrical copper wire by DC-power. A DC-controlled power supply: Model No: HQ3003SIII, supplied by Hansheng Puyuan Technology Beijing Co., Ltd (Beijing, China), with the ranges (0-3A and $0-30 \mathrm{~V}$ ), was used. Meanwhile, from top to bottom, space was filled with granular activated carbon (GAC) as third particle electrodes 


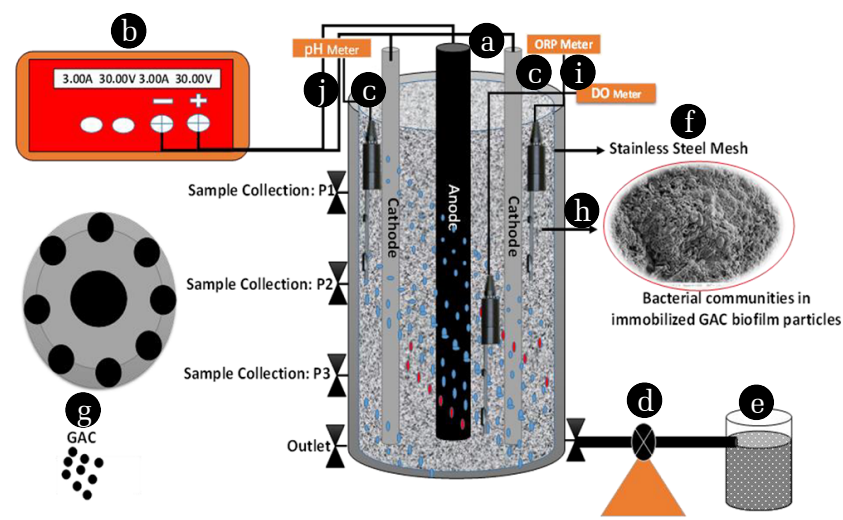

Fig. 1. Schematic diagram of the 3D-BERS reactor. (a) Graphite anode $\operatorname{rod}(\times 1)$ Size $(200 \mathrm{~mm} \times 15 \mathrm{~mm})$; (b) DC regulated power supply; (c) Graphite cathode rods $(\times 8)$ size $(200 \times 8 \mathrm{~mm})$; (d) Peristaltic Pump BT300-2j; (e) Influent water tank; (f) Stainless steel mesh; (g) Granular activated carbon (GAC); (h) Bacterial communities in immobilized GAC biofilm particles; (i) Portable ORP meter model: pH100; (j) Digital pH meter model: pH100 and Sample Collection Points (P1, P2, and P3).

(size 1.5-3mm) used for microbial growth purchased from Younga chemical Technology (Nanjing, Jiangsu Co., Ltd., China). The GAC was the best option for developing bacteria on cathode and anode surfaces of the inner zone and bottom zone in the reactor. GAC pre-treatment was washed serval times with deionized water through a sulfuric acid solution $(0.01 \mathrm{M})$ and dried for 24 to $30 \mathrm{~h}$ at $110^{\circ} \mathrm{C}$ [35].

\subsection{Culture Development of Denitrifying Microorganism and Synthetic Wastewater}

The denitrifying microorganisms found the biofilm on the anode-cathode surfaces and third electrode GAC in the 3D-BER system. The simulated wastewater used in the batch experiments with different $\mathrm{COD} / \mathrm{NO}_{3}{ }^{-} \mathrm{-}$ ratio concentrations were prepared by diluting the same nutrients (including $\mathrm{NaNO}_{3}, \mathrm{CH}_{3} \mathrm{COONa}, \mathrm{KH}_{2} \mathrm{PO}_{4}$, and trace elements) with tap water. Therefore, the 3D-BER system were fed $0.785 \mathrm{~L}$ simulated wastewater containing: $30 \mathrm{mg} / \mathrm{L}$ $\mathrm{NO}_{3}{ }^{-} \mathrm{N}, 3.5 \mathrm{mg} / \mathrm{L} \mathrm{K}_{2} \mathrm{HPO}_{4}, 4.5 \mathrm{mg} / \mathrm{L} \mathrm{NaCl}, 5.56 \mathrm{mg} / \mathrm{L} \mathrm{KH}_{2} \mathrm{PO}_{4}, 2.75$ $\mathrm{mg} / \mathrm{L} \mathrm{CaCl}_{2}$, and $0.5 \mathrm{~mL} / \mathrm{L}$ of concentrated trace elements stock solutions were prepared by dissolving; $15 \mathrm{~g} \mathrm{MgSO}_{4} \cdot 7 \mathrm{H}_{2} \mathrm{O}, 2.2 \mathrm{~g}$ $\mathrm{MnSO}_{4} \cdot \mathrm{H}_{2} \mathrm{O}, 2 \mathrm{~g} \mathrm{ZnSO}_{4} \cdot \mathrm{H}_{2} \mathrm{O}, 0.24 \mathrm{~g} \mathrm{CoCl}_{2} \cdot 6 \mathrm{H}_{2} \mathrm{O}, 2 \mathrm{mg} \mathrm{NiCl}{ }_{2} \cdot 6 \mathrm{H}_{2} \mathrm{O}$, $10 \mathrm{mg} \mathrm{FeCl}{ }_{3} \cdot 6 \mathrm{H}_{2} \mathrm{O}, 0.5 \mathrm{mg} \mathrm{CuCl} \cdot 2 \mathrm{H}_{2} \mathrm{O}, 0.5 \mathrm{mg} \mathrm{Na} \mathrm{MoO}_{4} \cdot \mathrm{H}_{2} \mathrm{O}$ and $15 \mathrm{~g} \mathrm{CaCl}_{2}$ into $1.2 \mathrm{~L}$ deionized water [8, 36, 37]. An enrichment phase has been extended to the denitrifying bacteria and the system dominant microorganisms [38]. The synthetic influent wastewater $\mathrm{pH}$ was adjusted by hydrochloric acid (HCL) or Sodium hydroxide $(\mathrm{NaOH})$. The influent wastewater was usually maintained by 7.5 \pm 0.2 , and no further adjustment is required.

\subsection{Biofilm Development and System Start-up}

The 3D-BER system was initially started for 90 days with abundant anaerobic sludge (Mixed liquor suspended sludge (MLSS) of about $5.55 \mathrm{~g} / \mathrm{L}$ ) was collected as a source of inoculation from the Nanjing municipal wastewater treatment plants (WWTPs) China. Before culti- vation, $1.2 \mathrm{~L}$ of anaerobic sludge water was placed into the refrigerator with nutritious solutions at $4^{\circ} \mathrm{C}$ for seven-days. During the first three days, sludge water was circulated by a magnetic pump. After 15 days, anaerobic sludge water was placed in the reactor, and $350 \mathrm{~mL}$ of tap water was added to a total volume of $785 \mathrm{~mL}$. It could also provide large surface areas for attachment and development of microorganisms. Nevertheless, electric current was not supplied to the 3D-BERs during cultivation after one week, the DC-power gradually used to $10 \mathrm{~mA}$. Biofilm, immobilisation, and acclimation were completed prior to the start of the batch experiments, and the anode-cathode electrodes and the third electrode converted GAC at room temperature $\left(27 \pm 1.5^{\circ} \mathrm{C}\right)$ into dark grey. However, the influent was renewed two times in $24 \mathrm{~h}$ to fast growth microorganism in the reactor, and samples were collected after ten days. The $\mathrm{NO}_{2}^{-}-\mathrm{N}, \mathrm{NO}_{3}^{-}-\mathrm{N}$, and denitrification efficiency were determined to evaluate the nitrate elimination in the 3D-BER system with GAC.

\subsection{Batch Experiments for the Denitrification Process}

The batch experiment was performed in the 3D-BER system to evaluate the performance of the denitrification process. In the $1^{\text {st }}$ phase of the experiments, the $\mathrm{COD} / \mathrm{NO}_{3}{ }^{-} \mathrm{N}$ concentration ratio ranged from ' 0 to $0.5,1$ to $1.5,2.5$ to 3.0 and 3.0 to 3.5 ' and the initial $\mathrm{NO}_{3}^{-}-\mathrm{N}$ concentration was $30 \pm 0.2 \mathrm{mg} / \mathrm{L}$, and the initial $\mathrm{pH}$ level was $7.0 \pm 0.1$. In addition, the initial $\mathrm{pH}$ was set at $6.0 \pm 0.2,6.5 \pm 0.5,7.0 \pm 0.1,7.5 \pm 0.4,7.8 \pm 0.6,8.2$ \pm 0.3 in the $2^{\text {nd }}$ phase of the experiment, and the initial $\mathrm{NO}_{3}^{-}-\mathrm{N}$ concentration was $30 \pm 0.2 \mathrm{mg} / \mathrm{L}$ with a $\mathrm{COD} / \mathrm{NO}_{3}{ }^{-} \mathrm{-N}$ ratio of 1.5 to 2.5. On average, the amount of nitrate and nitrite was 32 $\pm 0.2 \mathrm{mg} / \mathrm{L}$. The initial $\mathrm{NO}_{3}^{-}-\mathrm{N}$ concentration was $30 \pm 0.2 \mathrm{mg} / \mathrm{L}$ with the $\mathrm{COD} / \mathrm{NO}_{3}{ }^{-}-\mathrm{N}$ ratio and the initial $\mathrm{COD} / \mathrm{NO}_{3}{ }^{-}-\mathrm{N}$ ratio was 2.5-3.5 in the $3^{\text {rd }}$ phase of the experiments with initial $\mathrm{pH}$ were $6.0 \pm 0.2$ to $7.5 \pm 0.4$. Finally, in the $4^{\text {th }}$ phase of the experiments, when the $\mathrm{COD} / \mathrm{NO}_{3}{ }^{-} \mathrm{N}$ ratio was 0 to 3.5 , and the initial concentrations of $\mathrm{NO}_{3}^{-}-\mathrm{N}$ were $30 \pm 0.2,20 \pm 0.5$, and $10 \pm 0.7 \mathrm{mg} / \mathrm{L}$ with initial $\mathrm{pH}$ were $6.5 \pm 0.5$ to $8.2 \pm 0.3$, respectively (Table. S1). However, the concentration of $\mathrm{NO}_{3}{ }^{-} \mathrm{N}$ in the influent was maintained at $30 \pm 0.2 \mathrm{mg} / \mathrm{L}$ with an initial $\mathrm{pH}$ level. All batch experiments were performed in triplicate and repeated at least three times. Preliminary experimental findings indicate that immobilised microbes can achieve reasonably stable results within 8 $\mathrm{h}$ in 3D-BER systems with GAC. As a result, the batch test sampling time was regulated within $8 \mathrm{~h}$, and the sampling was carried out at $0.5 \mathrm{~h}, 1 \mathrm{~h}, 2 \mathrm{~h}$ and $3 \mathrm{~h}$ intervals. The 3D-BER system performance was cultivated on the GAC particle electrode to maintain denitrifying bacteria anaerobic conditions. The inoculum bacteria are a sufficient and complicated microbial inoculum purchased from BIONETIX ${ }^{\circledR}$ International Ltd. Co. Canada. This microbial group contains 32-strains of superficial bacteria and innumerable enzymes related to bioremediation. On the GAC biofilm surface of carriers, Proteobacteria, Thauera, Geobacter, Desulfomicrobium, Bacteroidetes, Sporomusa, Denitratisoma, and Thauera were the dominants $[23,29]$. The $\mathrm{NO}_{3}^{-}-\mathrm{N}$ concentration in the reactor, when nitrogen was exhausted, the residual substrate was removed, and fresh substrate was needed to avoid the endogenous bacteria metabolism. Then dissolved nitrogen species were measured immediately after sampling. 


\subsection{DNA Extraction, PCR Amplification, and MiSeq- Pyrosequencing}

The genus description of DNA extraction and PCR amplification of $16 \mathrm{~S}$ rDNA can be found previously. However, the biofilm samples were taken from the reactor after the three-month denitrification process and then dried by the freeze-drying system. The inner surface (IS) and bottom surface (BS) GAC particles electrodes biofilm were divided from the cubic feet rooftop cargo carrier (STDY-20). The biofilm samples were extracted and purified by PowerSoil-DNA Extraction Kit (MOBIO Laboratories, Carlsbad, CA92010, USA) [34].

The bacterial diversity was analyzed by Illumina-MiSeq-pyrosequencing within primers-338F (5'-ACTCCTACGGGAGGCCA GCA-3'), and 806 R (5'-GGACTAHVGGGTWTCTAAT-3') amplified the hypervariable zones at V3-V4 of the bacterial 16r RNA protein sequence [39] using PCR thermal cycler system (PE300, Stuttgart, Germany) [11]. The PCR reaction was performed in the following manner: denaturation at $3 \mathrm{~min}$ for $95^{\circ} \mathrm{C}$, annealing at $55^{\circ} \mathrm{C}$ for $30 \mathrm{~s}$, extension at $72^{\circ} \mathrm{C}$ for $10 \mathrm{~min}, 27$ cycle of $30 \mathrm{~s}$ at $95^{\circ} \mathrm{C}$, and elongation at $72^{\circ} \mathrm{C}$ for $45 \mathrm{~s}$ [39]. However, PCR reaction was performed three-times at $20 \mu \mathrm{L}$ mixed with $4 \mu \mathrm{L}$ of $5 \times$ buffer FastPfu, $20-\mu \mathrm{L}$ of $2.5 \mathrm{mM}$ deoxyribonucleotide triphosphate (dNTP), 0.8 $\mu \mathrm{L}$ of $5 \mu \mathrm{M}$ of separate primer, $0.4 \mu \mathrm{L}$ of FastPfu polymerase and 10 ng of template-DNA. The PCR amplification product results were carried agarose-gel $2.2 \%$, and required further purified by the AxyPrep ${ }^{\mathrm{TM}}$ DNA gel-extraction Kit (Thermo Fisher Scientific, Marseille, France) and measured by QuantiFlour TM-St Fluorometer Method (Thermo Fisher Scientific, Los Angeles, USA) [39, 40]. The purified amplicons of all samples were pooled in equimolar concentrations analyzed by sequencing on a high throughput Illumina-MiSeq platform with paired-end sequencing ( 2 x 250-bp), according to the standard protocols by Novogene Co., Ltd., Beijing, China.

\subsection{Biofilms Samples Analysis by SEM on GAC Particles Electrodes}

The IS and BS-GAC particles electrodes surface morphology for bacteria in biofilms was examined by scanning electron microscopy (SEM). Before SEM analysis, a series of batch experiment sample processing techniques (i.e., fixing, washing, dehydration, drying, coating, etc.) were applied. Approximately $0.8 \mathrm{~g}$ of the biofilm sample was placed in a $10 \mathrm{~mL}$ centrifuge-tube and centrifuged at 6,000 rpm for $5 \mathrm{~min}$. At that time, the supernatant was removed, and then $7 \mathrm{~mL}$ of $2.5 \%$ glutaraldehyde was added to mix with the sediment sample at the bottom of the centrifuge tube. Place the centrifuge tube in the refrigerator at $4^{\circ} \mathrm{C}$ for 3 to $4 \mathrm{~h}$ to fixed the sample [41]. Afterwards, the tube was centrifuged for centrifugation at 6,000 rpm for $5 \mathrm{~min}$, and the supernatant was removed after the centrifugation process. Add about $7 \mathrm{~mL}$ of ultrapure water to the biofilm sample left at the bottom of the centrifuge tube, centrifuge again at $6,000 \mathrm{rpm}$ for $5 \mathrm{~min}$, and then remove the supernatant. Such washing was performed three times by centrifugation. Next phase, the washed biofilm was dehydrated with $7 \mathrm{~mL}$ of $20 \%, 40 \%, 50 \%, 70 \%, 80 \%$, and $90 \%$ ethanol for $10 \mathrm{~min}$. The biofilm sample was dehydrated 3-times, with approximately $7 \mathrm{~mL}$ of $100 \%$ ethanol for $15 \mathrm{~min}$ each time. However, $7 \mathrm{~mL}$ of a mixture of ethanol and isoamyl acetate (100\% ethanol: isoamyl acetate $=1: 1$ ) were poured into the centrifuge tube for $15 \mathrm{~min}$. Although, pure isoamyl acetate was added and replaced for $20 \mathrm{~min}$. Finally, the settled samples were placed on filter paper $(10 \mathrm{~mL})$ and dried in a vacuum dryer (Mecha-Tech system Co.Ltd, $\mathrm{UK}$ ) at a pre-cooling temperature of $10^{\circ} \mathrm{C}$ for $24 \mathrm{~h}$. Dry, then detonate with a $10 \mathrm{~nm}$ gold layer [11, 42].

The coated samples were examined with (Hitachi S-4300 FEG-SEM, Austin, USA), and the images were captured digitally. The SEM images are shown in Fig. 2, the morphology of biofilm attached to granular activated carbon (GAC) particle electrodes in the 3D-BERs. The GAC had a high specific area of about 450-900 $\mathrm{m}^{2} / \mathrm{g}$ and a porous structure to facilitate microbial attachment growth, as reported [24]. The biofilm samples of the inner surface (IS) were abundant compared to the bottom surface (BS) and original sludge (OS), corresponding to the thicker bacterial community. In the IS, OS zone, the microbes are less in quantity due to lacking electron donors. It was found that in the 3D-BERs with immobilized GAC, biofilm was embedded in the abundance of microbial activity $[24,28]$. It was clearly observed in rod-shaped graphite anode and cathode, which was authentic in the other denitrification system $[11,16]$. There also existed giant microbes, which may be hydrogen-heterotrophic denitrifying bacteria.

\subsection{Analytical Methods and Calculations}

All effluent samples were filtered by $0.45 \mu \mathrm{m}$ membrane filters (Millipore, Germany) before the analysis. Before calculating the
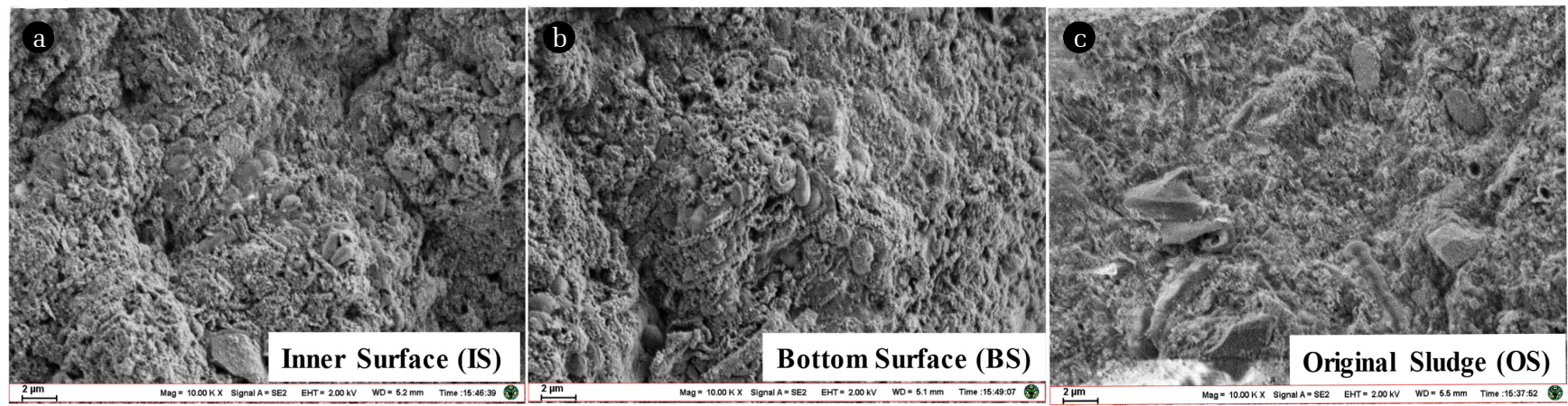

Fig. 2. SEM images of (a) inner surface (IS), (b) bottom surface (BS), and (c) original sludge biofilm samples in 3D-BERs (experimental conditions: $\left.\mathrm{COD} / \mathrm{NO}_{3}^{-}-\mathrm{N}=1.5-3.5, \mathrm{pH}=7.5 \pm 0.4, \mathrm{~T}=24.5 \pm 0.5^{\circ} \mathrm{C}\right)$ 
indexes, the data was obtained through average repeated sampling [43]. $\mathrm{N}-\mathrm{NO}_{3}{ }^{-}$, was measured by an ultraviolet spectrophotometric (Shimadzu UV-1800, Japan) method at wavelength $\lambda=220-275$ $\times 2 \mathrm{~nm}$. Specifically, $\mathrm{N}-\mathrm{NO}_{2}^{-}$was analyzed by $\mathrm{N}-(1-n a p h t h y l-1$, 1-ethylenediamine dihydrochloride) spectrophotometric method at $\lambda=540 \mathrm{~nm}$, respectively. The $\mathrm{pH}$ and ORP were measured by a pH meter model pH-100 (Shanghai Yoke Instrument Co., Ltd., China). The chemical oxygen demand (COD) was analyzed by the acidic potassium dichromate oxidation method (Digital thermos reactor, DRB200, Germany). Dissolved Oxygen (DO) value was measured by a portable DO-meter (GWQ-DO280, Xian Gavin Electronic Technology Co., Ltd China). While monitoring the temperature during the experiments installed an insertion thermometer in the reactor. All samples were stored at $4^{\circ} \mathrm{C}$ prior to the analysis. At least three samples were taken for each test. The removal performance of nitrate and rate were determined using the formulas $\left(\mathrm{C}_{1}-\mathrm{C}_{2} / \mathrm{C}_{1}\right.$ $\mathrm{X} 100)$ and $\left(\mathrm{C}_{1}-\mathrm{C}_{2}\right) / T$, respectively. Where " $\mathrm{C}_{1}$ " was the initial influent concentration of nitrate, and the " $\mathrm{C}_{2}$ " was the final effluent concentration of nitrate, and "T" is the reaction time.

\section{Results and Discussion}

\subsection{The Removal Performance of Nitrates under Different Initial $\mathrm{pH}$ and $\mathrm{COD} / \mathrm{NO}_{3}{ }^{-}-\mathrm{N}$ Ratios}

The removal performance in the organic carbon-based denitrification system is the main source of bacterial respiration and better growth during heterotrophic denitrifying enzymes (Fig. S1).
In the case of an initial $\mathrm{NO}_{3}{ }^{-}-\mathrm{N}$ concentration of $30 \pm 0.2 \mathrm{mg} / \mathrm{L}$ and an initial $\mathrm{pH}$ of $7.5 \pm 0.4$, the level of $\mathrm{COD} / \mathrm{NO}_{3}{ }^{-} \mathrm{N}$ ratio was observed in the range of 0.5-3.5 by adding different amounts of sodium acetate as a carbon source. Under the influence of the $\mathrm{COD} / \mathrm{NO}_{3}^{-}-\mathrm{N}$ ratios, the changes of the residual $\mathrm{NO}_{3}{ }^{-}-\mathrm{N}, \mathrm{NO}_{2}-\mathrm{N}$, and the sum of the concentrations of initial $\mathrm{NO}_{3}{ }^{-}-\mathrm{N}$ and $\mathrm{NO}_{2}^{-}-\mathrm{N}$ within $8 \mathrm{~h}$ were observed in Fig. 3(a)-(b), respectively. As shown in Fig. 3(a), without adding sodium acetate as a carbon source, the denitrification process is fragile. However, in this study, the presence of a definite amount of carbon source, the concentration of $\mathrm{NO}_{3}{ }^{-} \mathrm{N}$ has an identical tendency at different ratios of $\mathrm{COD} / \mathrm{NO}_{3}^{-}-\mathrm{N}$, and it drops rapidly within the first $1.5 \mathrm{~h}$ and then stabilizes. Since the $\mathrm{COD} / \mathrm{NO}_{3}{ }^{-} \mathrm{-N}$ ratio increased from 0.5 to 1.0, the residual concentration of $\mathrm{NO}_{3}^{-}-\mathrm{N}$ was not significantly reduced. An optimal level of $\mathrm{COD} / \mathrm{NO}_{3}^{-} \mathrm{-N}$ ratio of 1.5 has the maximum removal of nitrate, while $\mathrm{NO}_{3}{ }^{-} \mathrm{N}$ completely removed in $1.2 \mathrm{~h}$. As described in Fig. 3(b), the carbon source addition results in a decrease in $\mathrm{NO}_{2}{ }^{-} \mathrm{N}$ within $8 \mathrm{~h}$ and the suitable accumulation of nitrite. While the $\mathrm{COD} / \mathrm{NO}_{3}{ }^{-} \mathrm{N}$ ratio is between 1.5 and 2.5, the nitrite concentration reaches $1.98 \mathrm{mg} / \mathrm{L}$ to $1.02 \mathrm{mg} / \mathrm{L}$ in 2.5 $\mathrm{h}$, and then rapidly decreasing almost $0 \mathrm{mg} / \mathrm{L}$ within $8 \mathrm{~h}$. But, at the $\mathrm{COD} / \mathrm{NO}_{3}^{-}-\mathrm{N}$ ratios of 1.0 and 2.5 , the nitrite concentration increased to the highest at $1.5 \mathrm{~h}$ and then gradually declined, causing a definite amount of nitrite to accumulate in $5 \mathrm{~h}$ [44]. Simultaneously, when the $\mathrm{COD} / \mathrm{NO}_{3}{ }^{-} \mathrm{-N}$ ratio was 0.5 and 1.0 , the corresponding denitrification efficiency was low. As shown in Fig. 3(c), the denitrification efficiency was $49.43 \%$ and $61.12 \%$ at $4.5 \mathrm{~h}$. When the $\mathrm{COD} / \mathrm{NO}_{3}{ }^{-} \mathrm{N}$ ratio was 1.5 , the denitrification
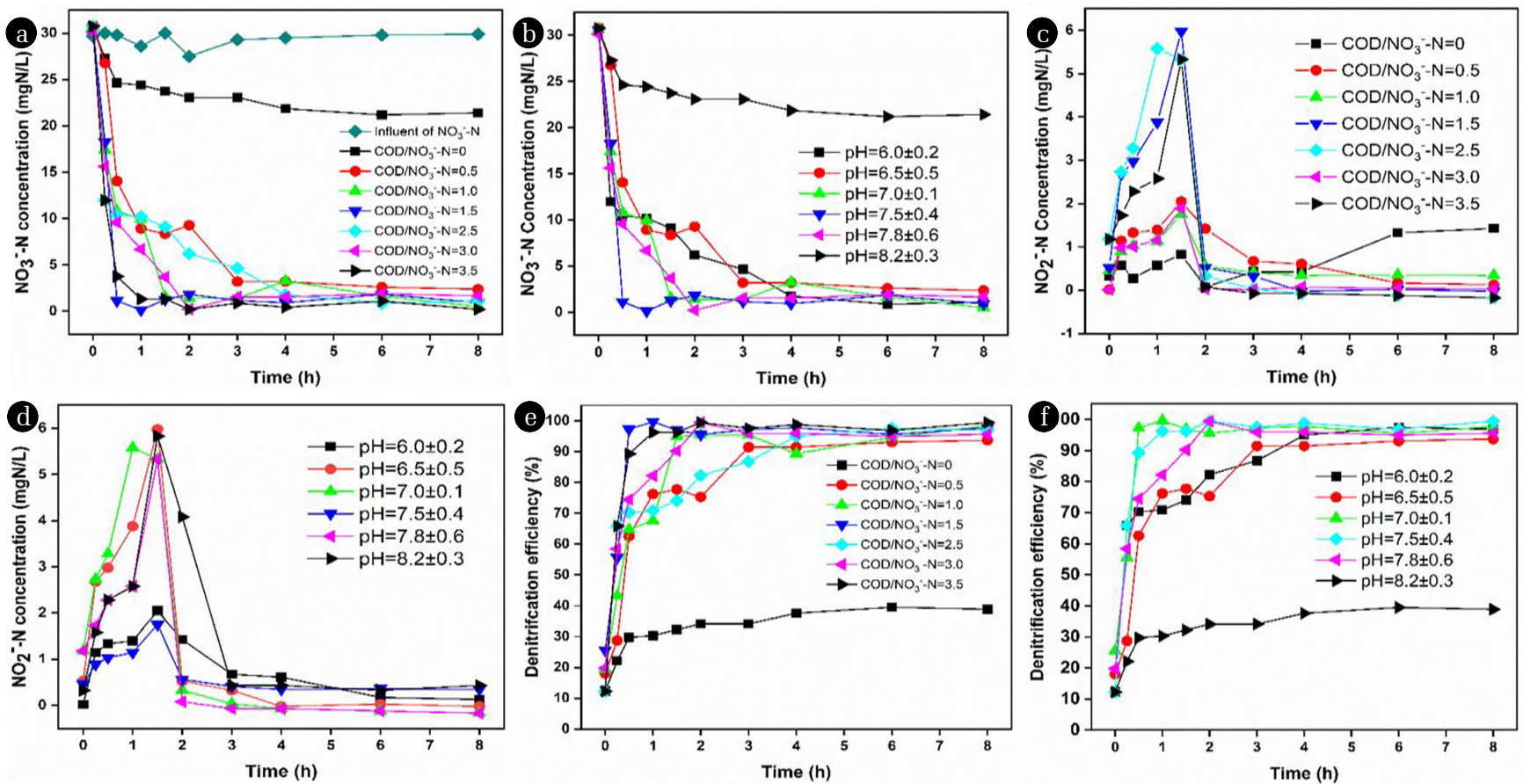

Fig. 3. The concentration and removal performance of $\mathrm{NO}_{3}{ }^{-} \mathrm{N}(\mathrm{a}-\mathrm{b}), \mathrm{NO}_{2}{ }^{-} \mathrm{N}(\mathrm{c}-\mathrm{d}$ ), and denitrification efficiency (e-f) with different pH levels of $\mathrm{NO}_{3}{ }^{-} \mathrm{N}, \mathrm{NO}_{2}{ }^{-} \mathrm{N}$, and denitrification during heterotrophic-autotrophic denitrification process, under the experimental conditions: i.e., $\mathrm{pH}=6.0 \pm 0.2$ to $8.2 \pm 0.3$, with initial concentration of $\mathrm{NO}_{3}{ }^{-} \mathrm{N}=30 \pm 0.2 \mathrm{mg} / \mathrm{L}$, and the $\mathrm{COD} / \mathrm{NO}_{3}{ }^{-} \mathrm{N}$ ratio from 0 to 3.5 , respectively. 
efficacy within $3 \mathrm{~h}$ reaches $98.62 \%$, as compared to $81.12 \%$ when the $\mathrm{COD} / \mathrm{NO}_{3}{ }^{-} \mathrm{N}$ ratio was $3.5[15,37,45]$. As a result, the increasing $\mathrm{COD} / \mathrm{NO}_{3}{ }^{-}-\mathrm{N}$ ratio from 2.0 to 3.0 did not significantly improve the denitrification efficiency. The increased carbon source contained substantially impacted nitrate removal performance as it provided sufficient carbon sources to meet the nutrients needed for bacterial cell growth $[8,46]$.

Heterotrophic-autotrophic denitrification is the process of biological nutrient removal by microorganisms using nitrate or nitrite [47] as a nitrogen source for microbial activity development and metabolism [24], similar results were reported in the previous works [30, 48, 49]. As the carbon source used as an electron donor was significant for the complete reduction of nitrates to nitrogen gas $[37,39,50]$. The time-lapse of the concentration change of nitrate and nitrite were presented in Fig. 3. The COD/ $/ \mathrm{NO}_{3}{ }^{-} \mathrm{N}$ ratio had a significant effect on reducing nitrate compared to reducing nitrites, with an appropriate increase in $\mathrm{COD} / \mathrm{NO}_{3}-\mathrm{N}$ ratio, to alleviate nitrite accumulation [14, 51]. Although the substrate electrons were reduced, the competitive advantage of electrons for nitrite reduction enzymes was not as good as that of nitrate reductases. Isaka et al. [39] reported that the activated energy needed for a nitrite reduction was higher than the removal of nitrates. The accumulation of nitrite can indicate an adequate amount of carbon sources. In the denitrification process, nitrate removal was an intermediate step and a rate-limiting step that greatly adjusted denitrification efficiency. Comparison with similar studies in the literature is summarized in Table 1, indicating that mutual autotrophic and heterotrophic denitrification has major significant advantages. Compared to autotrophic and heterotrophic denitrification, the apparent advantage is high treatment capability and high removal efficiency [46, 52]. The lower utilization of organic carbon sources and no organic pollution make the process better than traditional systems [2, 17, 30].

In general, the reduction of nitrite was more complicated due to changes in the $\mathrm{COD} / \mathrm{NO}_{3}{ }^{-} \mathrm{N}$ ratio, and when the $\mathrm{COD} / \mathrm{NO}_{3}{ }^{-} \mathrm{N}$ ratio increased to a certain amount, providing ample electrons for thorough denitrification, the accumulation of nitrite was effectively suppressed, and the efficacy of denitrification was enhanced [28]. When sodium acetate is used as an electron donor, the complete denitrification ratio of nitrate to nitrogen gas is 1.5, as displayed in Eq. (1) [48].

$$
\begin{gathered}
8 \mathrm{NO}_{3}^{-}+5 \mathrm{CH}_{3} \mathrm{COO}^{-}+8 \mathrm{H}= \\
4 \mathrm{~N}_{2}+5 \mathrm{CO}_{2}+5 \mathrm{HCO}_{3}^{-}+9 \mathrm{H}_{2} \mathrm{O}
\end{gathered}
$$

However, in this work, an appropriate $\mathrm{COD} / \mathrm{NO}_{3}{ }^{-}-\mathrm{N}$ ratio is required with additional cost and an excess amount of biomass in cognizance to improve denitrification efficiency. However, nitrogen will be used for bacterial growth [16, 28]. This immobilization process in the 3D-BERs achieves high nitrogen removal efficiency with a lower carbon source than previous studies [21]. The $\mathrm{pH}$ of the living environment of microorganisms may substantially affect bacterial enzyme activity in the reaction system. The effect of the initial $\mathrm{pH}$ on denitrification processes with an initial $\mathrm{NO}_{3}{ }^{-}-\mathrm{N}$ concentration of $30 \pm 0.2 \mathrm{mg} / \mathrm{L}$ and $\mathrm{COD} / \mathrm{NO}_{3}{ }^{-} \mathrm{N}$ ratio of 2.0 to 3.5 is displayed in Fig. 3(d)-(f), respectively [28, 56]. Fig. 3(d) shown that the concentration of $\mathrm{NO}_{3}^{-}-\mathrm{N}$ dropped suddenly and remained at nearby $0 \mathrm{mg} / \mathrm{L}$ at 1.2 to $2.2 \mathrm{~h}$ at $\mathrm{pH}$ of $6.5 \pm 0.5,7.0 \pm 0.1$, and $7.5 \pm 0.4$, respectively $[57,58]$. Since the concentration of $\mathrm{NO}_{3}{ }^{-}-\mathrm{N}$ was dropped to the minimum level of $0 \mathrm{mg} / \mathrm{L}$ after 1.2 $\mathrm{h}$, the excellent ability to reduce nitrates was shown at an initial $\mathrm{pH}$ of $7.5 \pm 0.4[50,52,59]$.

As shown in Fig. 3(e), the effect of $\mathrm{pH}$ on the removal of $\mathrm{NO}_{2}{ }^{-}-\mathrm{N}$ was significant. When the initial $\mathrm{pH}$ was $6.5 \pm 0.5,7.0 \pm 0.1$, and $8.2 \pm 0.3$, the $\mathrm{NO}_{2}^{-}-\mathrm{N}$ concentration increase to a peak level of 3.5 to $5.8 \mathrm{mg} / \mathrm{L}$ at $1.8 \mathrm{~h}$ and ultimately dropped to $0.22,0.12$, and $0.89 \mathrm{mg} / \mathrm{L}$ in the final effluent, respectively. While the concentration of $\mathrm{NO}_{2}^{-}-\mathrm{N}$ decreased from $5.8 \mathrm{mg} / \mathrm{L}$ in $1.2 \mathrm{~h}$, and $0 \mathrm{mg} / \mathrm{L}$ within $3.8 \mathrm{~h}$ with an initial $\mathrm{pH}$ of $7.8 \pm 0.6$ [42]. In general, the accumulation of $\mathrm{NO}_{2}{ }^{-}-\mathrm{N}$ was a severe problem at $1-5.9 \mathrm{mg} / \mathrm{L}$, and the initial $\mathrm{pH}$ was observed at $8.2 \pm 0.3[28,47]$. As illustrated in Fig. 3(f), the applicable denitrification efficiency has occurred between the initial $\mathrm{pH}$ values of $6.5 \pm 0.5$ and $7.5 \pm 0.4$. The initial $\mathrm{pH}$ of $7.5 \pm 0.4$ seems to be the best condition for the denitrification efficiency achieved $97.7 \%$ at $3.5 \mathrm{~h}$. When the $\mathrm{pH}$ was $7.0 \pm 0.1-7.5 \pm 0.4$, the diversity of microbial immobilization in the 3D-BER system, denitrification efficiency is high, immobilized microorganisms appear to be neutral in the alkaline environ-

\begin{tabular}{|c|c|c|c|c|c|c|c|}
\hline Influent type & $\begin{array}{l}\text { Types of } \\
\text { reactor }\end{array}$ & $\mathbf{H} / \mathbf{A}$ & Electric Current & C/N Source & $\begin{array}{l}\text { E.V } \\
\text { (L) }\end{array}$ & $\begin{array}{c}\text { Removal } \\
\text { efficiency (\%) }\end{array}$ & References \\
\hline Groundwater & BER & $\mathrm{H}$ & $200 \mathrm{~mA}$ & CH3COONa & 2.5 & 98 & {$[15]$} \\
\hline Synthetic wastewater & 3D-BERS-SAD & A & $400 \mathrm{~mA}$ & CH3COONa & 15 & 89.8 & [53] \\
\hline Low $\mathrm{C} / \mathrm{N}$ wastewater & CW-BER & & $15 \mathrm{~mA}$ & $\mathrm{C}_{6} \mathrm{H}_{12} \mathrm{O}_{6} \cdot 12 \mathrm{H}_{2} \mathrm{O}$ & 40 & 63.03-98.11 & [54] \\
\hline Synthetic wastewater & 3D-BER & A & $20-80 \mathrm{~mA}$ & Nano- $\mathrm{a}-\mathrm{Fe}_{2} \mathrm{O}_{3}$ & 1.5 & $90-96$ & [8] \\
\hline Synthetic contaminated groundwater & HAD-BER & A & $96.8-370 \mathrm{~mA} / \mathrm{m}^{2}$ & $\mathrm{CH}_{3} \mathrm{OH}$ & 0.78 & 99.8 & {$[55]$} \\
\hline Synthetic contaminated groundwater & BES & $\mathrm{H} \& \mathrm{~A}$ & $50 \mathrm{~mA}$ & PBS & 0.65 & $96.3 \pm 1.5$ & [9] \\
\hline Simulated municipal wastewater & 3D-BER & $\mathrm{H} \& \mathrm{~A}$ & $40 \mathrm{~mA}$ & CH3COONa & 3.4 & 98.3 & {$[33]$} \\
\hline Simulated municipal wastewater & 3D-BERS & $\mathrm{H} \& \mathrm{~A}$ & $60 \mathrm{~mA}$ & CH3COONa & 0.738 & 98.6 & Present Study \\
\hline
\end{tabular}

Table 1. Summary of the Operating Removal Performance of Different Types of Reactors in Previous Literature

Noted: 3D-BER: Three-dimensional biofilm electrode reactor; 3D-BERS-SAD: Three-dimensional biofilm electrode reactor with autotrophic sulfur denitrification; BES: Bioelectrochemical system; H/A: Heterotrophic/Autotrophic denitrification processes; E.V: Effective volume; PBS: Phosphate buffer solution; HAD-BER: Heterotrophic/biofilm autotrophic denitrification reactor; 3D-BERS: Three-dimensional bioelectrochemical reactor system 
ment, which was linked to another research study showing that denitrifying bacteria prefer the $\mathrm{pH}$ range of 6.2-8.2 [59,60].

The complete H-A denitrification reaction process, the GAC immobilized microorganisms, had a tremendous capability to remove nitrogen, even without $\mathrm{pH}$ regulation. It was believed that this microbial immobilization in the 3D-BER system can accept a wide range of $\mathrm{pH}$ values and acclimatize to $\mathrm{pH}$ variations, generally because the denitrification reaction be able to mitigate the effects of $\mathrm{pH}$ on the denitrifying bacteria [28], to some extent, the $\mathrm{pH}$ of microorganisms is maintained. Nevertheless, $\mathrm{pH} 8.2 \pm 0.3$ can be described as, when the initial $\mathrm{pH}$ environment was exceedingly alkaline, the inhibition of bacterial activity due to increasing the production of alkalinity during the denitrification processes would be emphasized [13]. Due to the competition between nitrite and electron reductase, excessive alkalization inhibits nitrite reduction enzymes, resulting in nitrite accumulation and low nitrogen reduction efficiency [34, 40].

\subsection{Removal Rate of $\mathrm{NO}_{2}^{-}-\mathrm{N} / \mathrm{NO}_{3}{ }^{-}-\mathrm{N}$ Concentration Ratios}

The effect of the initial $\mathrm{NO}_{2}{ }^{-}-\mathrm{N} / \mathrm{NO}_{3}{ }^{-}-\mathrm{N}$ concentration ratio on denitrification was investigated in the different $\mathrm{COD} / \mathrm{NO}_{3}{ }^{-}-\mathrm{N}$ ratio at the range of 0 to 3.5 , when the initial $\mathrm{NO}_{3}{ }^{-}-\mathrm{N}$ concentration was $30 \pm 0.2 \mathrm{mg} / \mathrm{L}$ and the initial $\mathrm{pH}$ was $7.5 \pm 0.4$. The nitrogen concentration revealed a comparable disparity tendency in the various initial concentrations of $\mathrm{NO}_{2}{ }^{-}-\mathrm{N} / \mathrm{NO}_{3}{ }^{-}-\mathrm{N}$ ratios, which decreased dramatically throughout the period and reached $0 \mathrm{mg} / \mathrm{L}$ at $4 \mathrm{~h}$ (Fig. 4(a)). When the $\mathrm{COD} / \mathrm{NO}_{3}{ }^{-}-\mathrm{N}$ concentration ratio was 1.5, the nitrogen concentration dropped below $0.5 \mathrm{mg} / \mathrm{L}$ and the denitrification efficacy exceeded $98.5 \%$ within $3.5 \mathrm{~h}[28,40]$. However, without the inlet of nitrite, the remaining nitrogen concentration was $4.58 \mathrm{mg} / \mathrm{L}$ at $1.5 \mathrm{~h}$. As illustrated in Fig. 4(b), the initial concentration $\mathrm{COD} / \mathrm{NO}_{3}-\mathrm{N}$ ratio increased from 0 to 1.5, the nitrite reduction and denitrification rate were raised, but the removal of nitrite was inhibited. The final results showed that the high concentration of $\mathrm{NO}_{2}{ }^{-} \mathrm{-N} / \mathrm{NO}_{3}{ }^{-} \mathrm{-N}$ ratio accelerated nitrites decline, and nitrate dropped was the main feature in regulating the complete denitrification rate.

From the literature based on the concentration of the substrates and carrier structure, oxygen was not spread through a GAC-immobi- lization carrier, resulting in low dissolved oxygen on the inner surface of the 3D-BER system. Also, the reductase of nitrite is more complicated to the low concentration of dissolved oxygen during the enhancement of the denitrification process, and states from top to bottom microbial activity in the process of anoxic reducing nitrite may be effectively performed in the inner or middle zone of the GAC carriers [54, 61]. Therefore, when the nitrogen concentration is relatively high, then the substrates dissemination limitation becomes unstable, nitrogen is removed efficiently by the middle/inner to the bottom surface supporting the GAC carrier. It can be assumed that the inner region bacteria obtain more effective nitrogen removal [34]. Furthermore, the increasing initial concentration of $\mathrm{NO}_{2}{ }^{-}-\mathrm{N} / \mathrm{NO}_{3}{ }^{-} \mathrm{N}$ ratio was more positive impacts on the degradation of $\mathrm{NO}_{2}^{-}-\mathrm{N}$ than that of $\mathrm{NO}_{3}^{-}-\mathrm{N}$ [2], the purpose for which may be the reduced competition for nitrate reductase electrons shown in Fig. 4(b).

In the absence of nitrates, the reduction rate of nitrites is higher than the reduction of nitrates, as nitrate reducing enzymes can no longer compete with electrons and facilitate the transformation of an electron into nitrate nitrite as a similar study was also reported [52].

\subsection{Kinetic Linear Fitting Models at the Different Initial Concentration of $\mathrm{NO}_{3}{ }^{-} \mathrm{N}$}

The performance of nitrogen removal at various initial concentrations of $\mathrm{NO}_{3}^{-} \mathrm{-}$ was studied in the range of $10 \pm 0.7$ to 30 $\pm 0.2 \mathrm{mg} / \mathrm{L}$ and the concentration of $\mathrm{COD} / \mathrm{NO}_{3}{ }^{-} \mathrm{N}$ ratio was 1.5 to 3.5 with the initial $\mathrm{pH}$ of $7.5 \pm 0.4$, respectively. At different initial concentrations of $\mathrm{NO}_{3}{ }^{-}-\mathrm{N}$, nitrogen in the system can be removed simultaneously, suggestive of the other initial nitrate levels would not influence in denitrification efficacy of these microbial activities in the GAC immobilization system. Nevertheless, it can affect the denitrifying removal rate (Fig. 5(a)).

To investigate the biological treatment of wastewater containing nitrate, the zero-order kinetic fitting model, the first-order kinetic fitting model, and the second-order kinetic fitting model were used to fit the denitrification removal rate of different concentrations of $\mathrm{NO}_{3}^{-}-\mathrm{N}$ at different time. The results of the kinetics fitting linear models were presented in Table 2. The rate of correlation of the
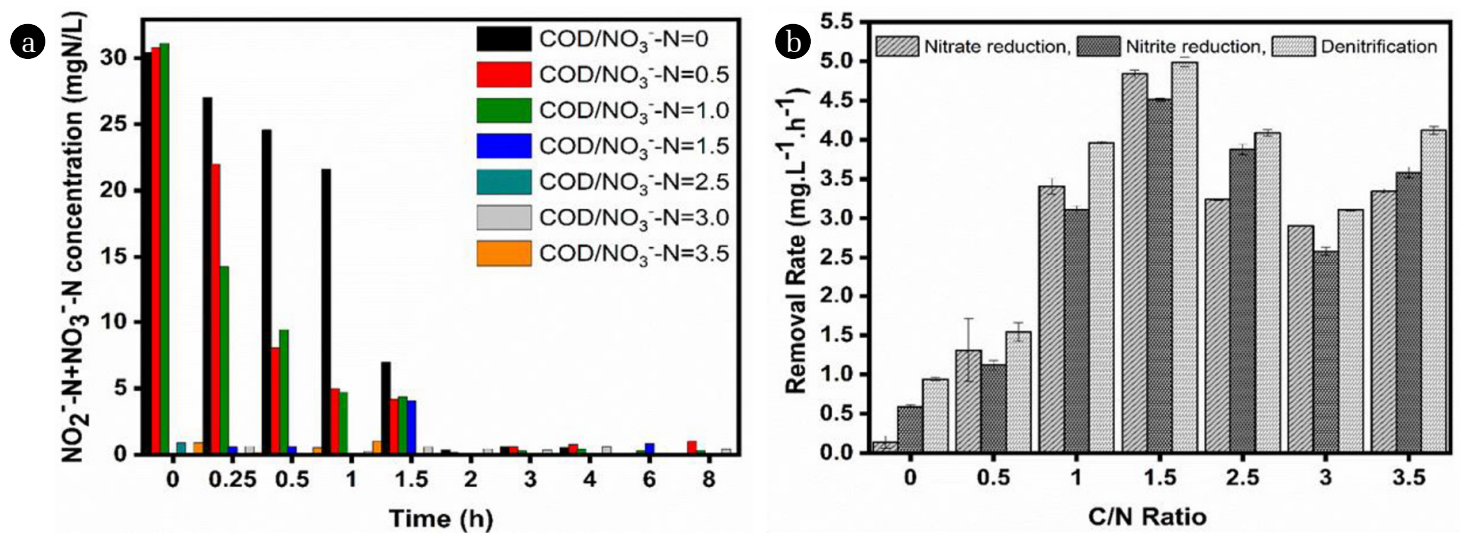

Fig. 4. Concentration profile of reduction of $\mathrm{NO}_{3}{ }^{-} \mathrm{N}$, and $\mathrm{NO}_{2}{ }^{-} \mathrm{N}$ accumulation/reduction rate: under different initial concentration $\mathrm{NO}_{2}{ }^{-}-\mathrm{N} / \mathrm{NO}_{3}{ }^{-}-\mathrm{N}$ ratios at $2.2 \mathrm{~h}$ with optimal $\mathrm{COD} / \mathrm{NO}_{3}{ }^{-} \mathrm{N}$ was 1.5 (a), and denitrification removal rate (b). 

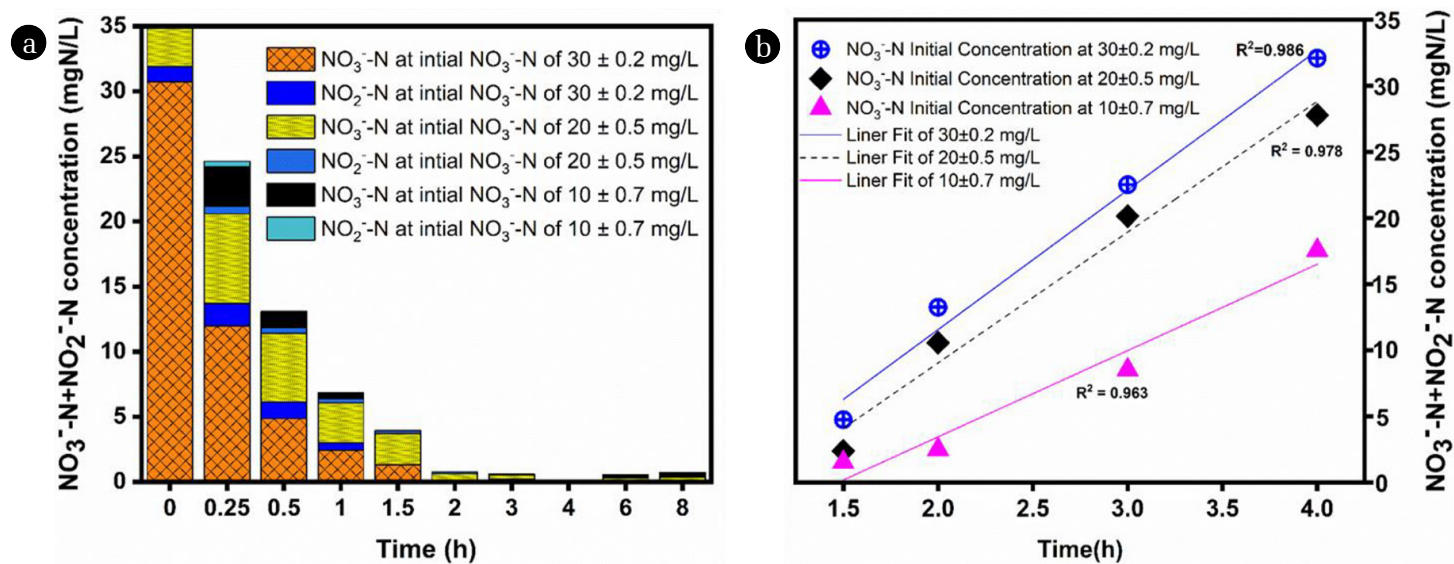

Fig. 5. Operational performance of the initial concentrations of $\mathrm{NO}_{3}^{-}-\mathrm{N}$ were: (a) at the different initial concentrations of $\mathrm{NO}_{3}^{-}-\mathrm{N}$, and (b) kinetics linear fitting models results.

Table 2. Analysis of Kinetic Fitting Linear Models at Different Initial Concentrations $\mathrm{NO}_{3}{ }^{-} \mathrm{N}$ in the 3D-BER System

\begin{tabular}{|c|c|c|c|c|}
\hline $\begin{array}{l}\text { Initial } \mathrm{NO}_{3}^{-} \\
\text {Nconcentration } \mathrm{mg} / \mathrm{L}\end{array}$ & $\begin{array}{c}\text { Reaction-Constant rate } \\
\mathrm{mg} /(\mathrm{L} \cdot \mathbf{h})\end{array}$ & $\begin{array}{l}\text { Correlation coefficient } \\
\text { factor }\left(\mathbf{R}^{2}\right)\end{array}$ & Standard Error (ER) & Kinetics models for $\mathrm{NO}_{3}^{-}-\mathrm{N} \mathrm{mg} / \mathrm{L}$ \\
\hline $10 \pm 0.7$ & 0.996 & 0.785 & 1.94 & \\
\hline $20 \pm 0.5$ & 0.874 & 0.675 & 0.44 & 1st order- Kinetics models \\
\hline $30 \pm 0.2$ & 0.987 & 0.892 & 0.12 & \\
\hline $10 \pm 0.7$ & 0.982 & 0.772 & 1.02 & \\
\hline $20 \pm 0.5$ & 0.785 & 0.953 & 0.58 & 2nd order- Kinetics models \\
\hline $30 \pm 0.2$ & 0.974 & 0.943 & 0.61 & \\
\hline $10 \pm 0.7$ & 1.986 & 0.963 & 1.10 & \\
\hline $20 \pm 0.5$ & 2.134 & 0.978 & 0.48 & Zero-order- Kinetics models \\
\hline $30 \pm 0.2$ & 3.954 & 0.986 & 0.71 & \\
\hline
\end{tabular}

coefficient constant $\left(\mathrm{R}^{2}=0.95\right)$ of the zero-order kinetics linear fit model of different initial $\mathrm{NO}_{3}{ }^{-}-\mathrm{N}$ concentrations was relatively more considerable than that of other fitting kinetics linear models. It was shown in Fig. 5(b), nicely combines the denitrification curve for different conditions with the zero-order fitting kinetics linear model, as described in Eq. (2)

$$
\mathrm{C}_{\mathrm{t}}=\mathrm{C}_{\mathrm{o}}-\mathrm{K}_{\mathrm{o}} \mathrm{t}
$$

Where $\mathrm{C}_{\mathrm{t}}$ and $\mathrm{C}_{\mathrm{o}}$ indicate the nitrate concentration (mg/L) at time $\mathrm{t}(\mathrm{h})$ in the influent and the effluent of the system, and $-\mathrm{K}_{\mathrm{o}} \mathrm{t}$ is the zero-order fitting kinetics linear rate constant $(\mathrm{mg} /(\mathrm{L} \cdot \mathrm{h}))$. The correlation rate of the coefficient constant was $R^{2}=0.986$. The zero-order fitting kinetics linear constant was $3.954 \mathrm{mg} /(\mathrm{L} \cdot \mathrm{h})$ with an initial concentration of $\mathrm{NO}_{3}{ }^{-}-\mathrm{N}$ was $30 \pm 0.2 \mathrm{mg} / \mathrm{L}$, which was higher compared to the zero-order fitting kinetics linear constant rate was $2.134 \mathrm{mg} /(\mathrm{L} \cdot \mathrm{h})$, and the correlation rate of the coefficient constant was $\mathrm{R}^{2}=0.978$, with an initial concentration of $\mathrm{NO}_{3}^{-}-\mathrm{N}$ was $20 \pm 0.5 \mathrm{mg} / \mathrm{L}$. While, the initial level of $\mathrm{NO}_{3}^{-}-\mathrm{N}$ was 10 $\pm 0.7 \mathrm{mg} / \mathrm{L}$, and the zero-order fitting kinetics linear constant rate was $1.986 \mathrm{mg} /(\mathrm{L} \cdot \mathrm{h})$, much lower through with the coefficient constant correlation rate was $\mathrm{R}^{2}=0.963$, presented in Table 2 .

These results indicate that the advanced biological nitrogen removal process was performed in the 3D-BER system. It was suitable for the description in zero-order-kinetic models presented, consistent with previous studies [62, 63]. Moreover, the inlet of nitrate concentration greatly influences the denitrification rate, and with the increase of nitrate concentration, the rate of denitrification also increases [2, 7]. While the denitrification increases by nearly 1.5 times when the initial level of nitrates increases by about 5 $\mathrm{mg} / \mathrm{L}$, which agreed well with the literature [38, 40]. This could be explained by the mass transfer-resistance in the immobilized cell system [62]. The higher the substrate concentration, the poorer the substrate-diffusion resistance, which can improve the substrate use and improve cell growth and metabolism [11, 64]. Therefore, at the initial nitrate concentration of $30 \pm 0.2 \mathrm{mg} / \mathrm{L}$, and a high denitrification rate of $3.954 \mathrm{mg} /(\mathrm{L} \cdot \mathrm{h})$ was achieved in this work. Compared to the latest study combining iron-reduced bacterium and iron cycles, the average nitrate removal rate was only 0.69 $\mathrm{mg} /(\mathrm{L} \cdot \mathrm{h})$ with the influent nitrate concentration of $10 \mathrm{mg} / \mathrm{L}[21$, 62]. Feng Su et al. [61] reported that the advantages of heterotrophic denitrification through immobilized bacteria.

\subsection{Analysis of Microbial Community}

\subsubsection{Rarefaction curve and clustering analysis}

Rarefaction analysis was employed to standardize and compare the abundance of observed taxon richness among samples and classify the representative of collected samples. Rarefaction curve 
was instigated by plotting the number of sequence samples compared to the number of operational taxonomic units (OTUs) observed. More than 50,000 sequences were achieved for each sample (Fig. S2(a)). Unweighted Unifrac distance cut-off values of samples OS, IS, and BS usually are accepted as points at which variation occurs in the genus and phylum level, respectively [24]. Rarefaction curves of sample OS, IS, and BS indicate that the slopes have a tendency to flatten, which means that sequence analysis describes almost complete bacterial inhabitants and the corresponding number of OTUs (Fig. S2(b)). The analysis of hierarchical clustering was used to show the divergence in the structure of bacterial communities in three samples, as shown in Fig. S2

\subsubsection{Diversity and bacterial communities structure analysis}

In this study, the 16S rDNA gene replicas investigation was directed to measure the microbial community structure in the 3D-BER system. Nevertheless, the bacterial community diversity characteristic of the original sludge (OS), the inner surface (IS), and bottom surface (BS) of immobilized GAC carriers were listed in Table S2. A total of 68614-82,006 useful sequences were achieved, after the quality control process of raw sequence data. The 891-1085 operational taxonomic units (OTUs) were clustered at 98.8\% similarity index, and the sequencing results were shown a reasonable replication of microbial diversity. Adequate coverage was relatively close to 1 . The value of Alpha $(\alpha)$ diversity of Simpson and Shannon index reduced in the inner surface (IS), except for the AceI index, which increased OS and BS samples tendency. It was revealed that the concentration of significant functional microorganisms occurred in IS. Then, the diversity of microbial communities did not change significantly in the OS and BS samples. More than 50,000 good reads were obtained in the sequence data processing system. Similarly, AceI and ChaoI index indicated an accumulative trend subsequently OS, IS, and BS samples showing the OTUs abundance was significantly higher in the IS area of GAC biofilm carriers, the changes consistent to the variations in the OTUs numbers. This can be attributed to the low concentration of $\mathrm{NO}_{3}^{-}-\mathrm{N}$ removal and the fact that MLSS was relatively stable during the whole operating period.

Fig. 6(a) and 6(b) show the relative microbial abundance at the genus and phyla levels in three samples through taxonomic analysis. At the genus level, the most important group of bacteria in the IS sample was Thauera, Geobacter, Desulfomicrobium, Sporomusa, and Denitratisoma, presenting for 40.06\%, 35.45\%, $2.81 \%, 4.59 \%$, and $2.51 \%$ of reads, respectively. Similarly, at the phylum level, the most abundant bacterial population in the IS sample was Proteobacteria, Bacteroidetes, Gracilibacteria, Tenericutes, and Firmicutes were presenting for 69.01\%, 15.88\%, $8.48 \%, 7.16 \%$, and $2.12 \%$ of reads, the domain phylum found in three samples, respectively [65]. As a result, phylum Proteobacteria play an important role in the denitrification process of immobilized GAC particles, meaning that the 3D-BERs exhibited excellent nitrate removal performance in the OS, IS, and BS biofilm GAC samples. In contrast, it was auxiliary copious in IS samples (69.01\%) compared to OS sample (49.8\%), and BS samples (60.16\%) [11]. On the GAC biofilm surface of carriers, Proteobacteria, Geobacter, Bacteroidetes, and Thauera were the dominants, accounting for $69.01 \%$, 35.45\%, $15.88 \%$, and $40.06 \%$, respectively.
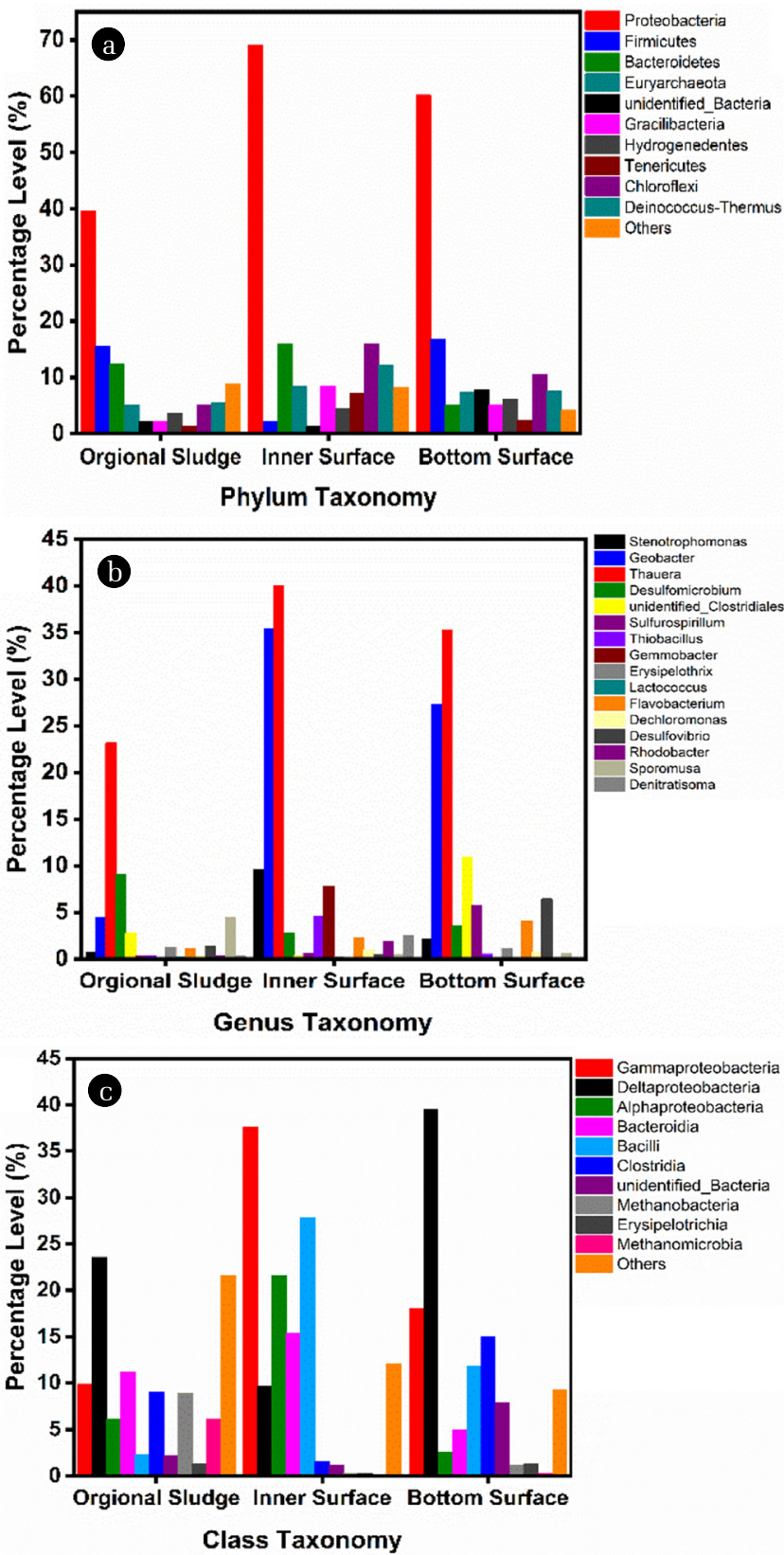

Fig. 6. Microbial community structure and relative abundance of the dominant bacterial taxa in three samples at the (a) genus level, (b) phylum level and class level in the original sludge, inner surface and bottom surface.

As shown in Fig. 6(c), Gammaproteobacteria, Deltaproteobacteria, Alphaproteobacteria, Bacteroidia, Bacilli, Clostridia, Methanobacteria and Erysipelotrichia were preponderant classes in OS, IS, and BS samples $[11,38,66]$. These results indicated that the changes of bacterial community structure stuck between IS and BS sample was different, however; in the abundance of Gammaproteobacteria accounted for $9.86 \%, 37.64 \%$ and $18.07 \%$ in OS, IS and BS samples, respectively. Gammaproteobacteria [66], Deltaproteobacteria, and Bacilli were compared to the immobilized GAC biofilm carrier 
in BS zone, it was abundantly present in the IS zone [41, 66]. Deltaproteobacteria was the dominant class in the nitrate-based heterotrophic-autotrophic denitrification system [46]. Deltaproteobacteria accounted for more than $37.64 \%$ of the bacteria in the different phases, while Gammaproteobacteria, Alphaproteobacteria, Bacteroidia, Bacilli, Clostridia, Methanobacteria and Erysipelotrichia constituted more than 5\%. Corresponding to the previous study, Deltaproteobacteria, Bacteroidia, Bacilli, and Clostridia were predominant class and played a critical role in the heterotrophic denitrification system [66, 67].

As shown in Table S2 that the IS immobilized GAC biofilm of the carrier possessed higher bacterial community diversity and richness. The immobilized GAC biofilm supports can protect microbes, bacterial-resistance, and other improved species with giant inhabitants sustained in the inner surface or middle region of carriers [67]. Deltaproteobacteria and Proteobacteria were the leading bacterial inhabitants placed in the IS zone of carriers [68]. Recently, Proteobacteria and Bacteroidetes can reduce nitrates and nitrites for the whole period of denitrification were studied in an anoxic condition [20, 68]. Bacteroidetes, Proteobacteria, and Firmicutes were the predominant phylum in this reactor [65] and often contributed to the denitrification process $[16,68]$. Similar results have been obtained by Wang et al. [69], the denitrification system phylum delimited Firmicutes and Proteobacteria, confirmed that Proteobacteria and Firmicutes were shown to have potential nitrate removal capabilities [70]. Deinococcus-Thermus from another study that Proteobacteria, Chloroflexi, and Tenericutes were the predominant microorganisms in a traditional biofilm-electrode reactor [57], wherever the Proteobacteria played significant roles in the performance of denitrification in the biofilm reactor $[49,58]$. It has been reported that Firmicutes, Proteobacteria, Deinococcus-Thermus, and Hydrogenedentes bacteria have a tendency to subsist in the anaerobic environment using organic nutrients and fatty acids source [17, 24, 68]. Therefore, in an anaerobic environment, the 3D-BER system with the GAC biofilm carriers may expedite Proteobacteria bacteria survival in the samples of original sludge, Inner surface, and bottom surface.

The microorganisms disturbed in the mycelium making networks [57], which can improve microbes capability to prevent the environmental variations and auxiliary carbon sources, play a vital role in municipal wastewater treatment systems [21]. According to the above-mentioned experimental findings, the essential denitrifiers Pseudomonas and diverse microbial communities contribute to the comprehensive removal of nitrate [52, 58]. In addition, the dominant communities were the biofilm GAC inner surface where Firmicutes and Proteobacteria may be the primary reasons for denitrification of the GAC immobilised bacteria. Denitrification processes mainly occurred in the IS anoxic condition, prominent to the presence of a certain mass transfer-resistance level [11, 41]. Accordingly, the removal rate of denitrification might be affected and controlled by substrate the nitrates initial concentration [52]. The organic carbon source in the 3D-BERs was supplemented with sodium acetate and sludge, and this would lead to a comparatively high-level proportion community of Proteobacteria (69.01\%), Bacteroidetes (15.88\%), Gracilibacteria (8.48\%), in the inner surface or middle surface of the reactor [50, 71].

In conclusion, bacterial activity in the GAC immobilization in the 3D-BER system was favourable for treating nitrate-polluted water. The complete nitrate or nitrite elimination would be analyzed by transmitting substrates in the GAC biofilm-immobilized cell and the nitrate to nitrite reductase enzymes. The microbial communities play a significant role in the GAC immobilized carriers composition with different operating parameters and in the groups distributed in the above processes. In the 3D-BER system with the GAC biofilm, immobilized microbial systems based on fully immobilized bacterial consortium provide space for various dominant microbial communities. Under the right circumstances, nitrates and intermediates can be efficiently removed according to a diverse microbial population. The best results of eliminating nitrogen and microbial community diversity in this study are enlightening for regulating and optimizing the GAC immobilization cell microbial communities and achieving better removal performance and needs for further research and application.

\section{Conclusions}

To effectively treat nitrate polluted water, a novel 3D-BER system using cooperation between autotrophic and heterotrophic denitrification has been developed. However, the nitrate removal efficiency was higher than $98 \%$ at $\mathrm{COD} / \mathrm{NO}_{3}{ }^{-}-\mathrm{N}$ ratio of 1.5 with HRT (1.2 h). There were various types of denitrifying microorganisms found in the 3D-BER system, which led to the removal performance of nitrates through denitrification processes. In the biofilm on the GAC particles electrode carriers of the reactor was dominated by Bacteroidia, Bacilli, Clostridia, $\alpha-\gamma-\delta$-proteobacteria, Desulfomicrobium, and Sporomusa became the main species in OS, IS and BS samples, respectively. The heterotrophic-autotrophic denitrification could simultaneously occur in the GAC carriers inner surface, where Thauera, Proteobacteria, and Firmicutes were the dominant microbial community. Nevertheless, with limited sludge and carbon sources, the diverse and dynamic bacterial activity composition in the treatment process can significantly improve the performance of the 3D-BER system and make it attractive denitrification for nitrate-polluted water. This research provided new insights into the application of the three-dimensional bioelectrochemical reactor system, and further efforts are needed to improve the efficiency of nitrates removal and look for suitable material for cathode and anode.

\section{Acknowledgment}

This scientific research work was financially supported by the Jiangsu Social Development Project (BE2018630), Wuxi Science and Technology Development Fund (WX18IVJN609) and the National Science Foundation of China (51578132).

\section{Author Contributions}

M.H. (Ph.D. Student) wrote novel research articles with the help of Supervisor and group teachers. G.Z. (Professor) revised the manuscript and Funding acquisition, as the corresponding author and 
helped revised the manuscript. Z.Y. (Assistant Professor) participated in drafting the article. Y.L. (Lecturer) provided suggestion and authoritative points to write novel research. S.H. (Ph.D. Student) revised it critically for important intellectual facts. Y.Y. (Ph.D. Student) participated in drafting and editing of the article. L.G. (Ph.D. Student) agreed to be accountable for all aspects of the work and also revised the manuscript.

\section{References}

1. Mortazavi-Derazkola S, Zinatloo-Ajabshir S, Salavati-Niasari M. Facile hydrothermal and novel preparation of nanostructured Ho2O3 for photodegradation of eriochrome black T dye as water pollutant. Adv. Powder Technol. 2017;28:747-754.

2. Kijjanapanich P, Yaowakun Y. Enhancement of Nitrate-Removal Efficiency Using a Combination of Organic Substrates and Zero-Valent Iron as Electron Donors. J. Environ. Eng. 2019;145: 04019006.

3. Boiocchi R, Gernaey KV, Sin G. Understanding N2O formation mechanisms through sensitivity analyses using a plant-wide benchmark simulation model. Chem. Eng. J. 2017;317:935-951.

4. Zinatloo-Ajabshir S, Salehi Z, Salavati-Niasari M. Green synthesis of Dy2Ce2O7 ceramic nanostructures using juice of Punica granatum and their efficient application as photocatalytic degradation of organic contaminants under visible light. Ceram. Int. 2018;44:3873-3883.

5. Li J, Jin R, Tian T, Wang J, Zhou J. Simultaneous removal of chromate and nitrate in a packed-bed bioreactor using biodegradable meal box as carbon source and biofilm carriers. Bioresour. Technol. 2016;207:308-314.

6. Cheng H-Y, Xu A-A, Awasthi MK, et al. Aerobic denitrification performance and nitrate removal pathway analysis of a novel fungus Fusarium solani RADF-77. Bioresour. Technol. 2020;295: 122250.

7. He Q, Song J, Zhang W, Gao S, Wang H, Yu J. Enhanced simultaneous nitrification, denitrification and phosphorus removal through mixed carbon source by aerobic granular sludge. $J$. Hazard. Mater. 2020;382:121043.

8. Wang S-Y, Yang X-Y, Meng H-S, Zhang Y-C, Li X-Y, Xu J. Enhanced denitrification by nano a-Fe2O3 induced self-assembled hybrid biofilm on particle electrodes of three-dimensional biofilm electrode reactors. Environ. Int. 2019;125: 142-151.

9. Cecconet D, Devecseri M, Callegari A, Capodaglio AG. Effects of process operating conditions on the autotrophic denitrification of nitrate-contaminated groundwater using bioelectrochemical systems. Sci. Total Environ. 2018;613:663-671.

10. Pelaz L, Gómez A, Letona A, Garralón G. Nitrogen removal in domestic wastewater. Effect of nitrate recycling and COD/N ratio. Chemosphere 2018;212:8-14.

11. Chai H, Xiang Y, Chen R, et al. Enhanced simultaneous nitrification and denitrification in treating low carbon-to-nitrogen ratio wastewater: Treatment performance and nitrogen removal pathway. Bioresour. Technol. 2019;280:51-58.

12. Zinatloo-Ajabshir S, Salavati-Niasari M. Preparation and characterization of nanocrystalline praseodymium oxide via a simple precipitation approach. J. Mater. Sci. Mater. Electron. 2015;26:5812-5821

13. Dhamole PB, Nair RR, D'souza S, Lele SS. Denitrification of high strength nitrate waste. Bioresour. Technol. 2007;98: 247-252.

14. Dong H, Wang W, Song Z, et al. A high-efficiency denitrification bioreactor for the treatment of acrylonitrile wastewater using waterborne polyurethane immobilized activated sludge. Bioresour. Technol. 2017;239:472-481.

15. Park HI. Nitrate reduction using an electrode as direct electron donor in a biofilm-electrode reactor. Process Biochem. 2005;40: 3383-3388.

16. Zhang Y, Wang L, Han W, et al. Nitrate removal, spatiotemporal communities of denitrifiers and the importance of their genetic potential for denitrification in novel denitrifying bioreactors. Bioresour. Technol. 2017;241:552-562.

17. Wang J. Chu L. Biological nitrate removal from water and wastewater by solid-phase denitrification process. Biotechnol. Adv. 2016;34:1103-1112.

18. Heidari-Asil SA, Zinatloo-Ajabshir S, Amiri O, Salvati-Niasari M. Amino acid assisted-synthesis and characterization of magnetically retrievable $\mathrm{ZnCo2O} 4-\mathrm{Co} 3 \mathrm{O} 4$ nanostructures as high activity visible-light-driven photocatalyst. Int. J. Hydrog. Energy. 2020;45:22761-22774.

19. Öztürk N, Bektaş TE. Nitrate removal from aqueous solution by adsorption onto various materials. J. Hazard. Mater. 2004;112:155-162.

20. Ma Q, Qu Y, Shen W, et al. Bacterial community compositions of coking wastewater treatment plants in steel industry revealed by Illumina high-throughput sequencing. Bioresour. Technol. 2015;179:436-443.

21. Joshi K, Rajan R, Srinikethan G, Saidutta MB. Biological denitrification with immobilized Pseudomonas Syringae on granular activated carbon using three phase draft tube spouted bed reactor. Int. J. Curr. Eng. Technol. 2014;4:3304-3309.

22. Ni B.-J, Pan Y. Denitrification processes for wastewater treatment. In: Isabel Moura, José J G Moura, Sofia R Pauleta, Luisa B Maia, eds. Metalloenzymes in Denitrification: Applications and Environmental Impacts. London: Royal Society of Chemistry; 2016. p. 368-418.

23. Jun LY, Yon LS, Mubarak NM, et al. An overview of immobilized enzyme technologies for dye and phenolic removal from wastewater. J. Environ. Chem. Eng. 2019;7:102961.

24. Xu D, Xiao E, Xu P, et al. Bacterial community and nitrate removal by simultaneous heterotrophic and autotrophic denitrification in a bioelectrochemically-assisted constructed wetland. Bioresour. Technol. 2017;245:993-999.

25. Walker G. Weatherley L. Biological activated carbon treatment of industrial wastewater in stirred tank reactors. Chem. Eng. J. 1999;75:201-206.

26. Zinatloo-Ajabshir S, Ghasemian N, Mehdi M-K, Masoud S-N. Effect of zirconia on improving NOx reduction efficiency of $\mathrm{Nd} 2 \mathrm{Zr2O} 7$ nanostructure fabricated by a new, facile and green sonochemical approach. Ultrason Sonochem. 2020;71:105376.

27. Rattanapan C, Boonsawang P, Kantachote D. Removal of H2S in down-flow GAC biofiltration using sulfide oxidizing bacteria from concentrated latex wastewater. Bioresour. Technol. 
2009;100:125-130.

28. Zhao Y, Zhang B, Feng C, et al. Behavior of autotrophic denitrification and heterotrophic denitrification in an intensified biofilm-electrode reactor for nitrate-contaminated drinking water treatment. Bioresour. Technol. 2012;107:159-165.

29. Bayat Z, Hassanshahian M, Cappello S. Immobilization of microbes for bioremediation of crude oil polluted environments: a mini review. Open Microbiol. J. 2015;9:48.

30. Firestone M. Biological denitrification. In: Frank J. Stevenson eds. Nitrogen in agricultural soils. American Society of Agronomy, Inc. Crop Science Society of America, Inc. Soil Science Society of America Inc; 1982. p. 289-326.

31. Hassan M, Zhu G, Yang Z, Lu Y. Effects of pH on Antibiotic Denitrification and Biodegradation of Sulfamethoxazole Removal from Simulated Municipal Wastewater by a Novel 3D-BER System. J. Environ. Eng. 2020;146:04020134.

32. Costa DD, Gomes AA, Fernandes M, da Costa Bortoluzzi RL. Using natural biomass microorganisms for drinking water denitrification. J. Environ. Manage. 2018;217:520-530.

33. Hao R, Li S, Li J, Meng C. Denitrification of simulated municipal wastewater treatment plant effluent using a three-dimensional biofilm-electrode reactor: operating performance and bacterial community. Bioresour. Technol. 2013;143:178-186.

34. Ge S, Peng Y, Wang S, Lu C, Cao X, Zhu Y. Nitrite accumulation under constant temperature in anoxic denitrification process: The effects of carbon sources and COD/NO3-N. Bioresour. Technol. 2012;114:137-143.

35. Huang S, Lu Y, Li X, Lu YZ. Tertiary denitrification and organic matter variations of secondary effluent from wastewater treatment plant by the 3D-BER system. Environ. Res. 2020;189: 109937.

36. Ciudad G, Rubilar O, Muñoz P, et al. Partial nitrification of high ammonia concentration wastewater as a part of a shortcut biological nitrogen removal process. Process Biochem. 2005;40: 1715-1719.

37. Calderón OAR, Abdeldayem OM, Pugazhendh A, Rene ER. Current Updates and Perspectives of Biosorption Technology: an Alternative for the Removal of Heavy Metals from Wastewater. Curr. Pollut. Rep. 2020;6:8-27.

38. Cao J, Zhang T, Wu Y, et al. Correlations of nitrogen removal and core functional genera in full-scale wastewater treatment plants: Influences of different treatment processes and influent characteristics. Bioresour. Technol. 2020;297:122455.

39. Isaka K, Kimura Y, Osaka T, Tsuneda S. High-rate denitrification using polyethylene glycol gel carriers entrapping heterotrophic denitrifying bacteria. Water Res. 2012;46:4941-4948.

40. Glass C, Silverstein J. Denitrification kinetics of high nitrate concentration water: $\mathrm{pH}$ effect on inhibition and nitrite accumulation. Water Res. 1998;32:831-839.

41. Cho JS, Park JY, Yoo YJ. Novel 3-dimensional bioelectrode for mediatorless bioelectrochemical denitrification. Biotechnol. Lett. 2008;30:1617.

42. Puig S, Serra M, Vilar-Sanz A, et al. Autotrophic nitrite removal in the cathode of microbial fuel cells. Bioresour Technol. 2011;102:4462-4467.

43. Federation W.E.A.P.H. Association, Standard methods for the examination of water and wastewater. American Public Health
Association (APHA): Washington, DC, USA. 2005.

44. Ruiz G, Jeison D, Charmy R. Development of denitrifying and methanogenic activities in USB reactors for the treatment of wastewater: Effect of COD/N ratio. Process Biochem. 2006;41: 1338-1342.

45. Elahi E, Weijun C, Sunil Kumar J, Huiming Z. Estimation of realistic renewable and non-renewable energy use targets for livestock production systems utilising an artificial neural network method: A step towards livestock sustainability. Energy 2019;183:191-204.

46. Xing W, Wang Y, Hao T, He Z, Jia F, Yao H. pH control and microbial community analysis with $\mathrm{HCl}$ or $\mathrm{CO} 2$ addition in H2-based autotrophic denitrification. Water Res. 2020;168: 115200.

47. Hassan M, Zhu G, Yang Z, et al. Effect of the C/N Ratio on Biodegradation of Ciprofloxacin and Denitrification from Low $\mathrm{C} / \mathrm{N}$ Wastewater as Assessed by a Novel 3D-BER System. Sustainability 2020;12:7611.

48. Rittmann BE, McCarty PL. Environmental biotechnology: principles and applications. Tata McGraw-Hill Education; 2012.

49. Corredor JE, Morell JM. Nitrate depuration of secondary sewage effluents in mangrove sediments. Estuaries. 1994;17:295-300.

50. Wu Z-y, Liu Y, Wang S-y, et al. A novel integrated system of three-dimensional electrochemical reactors (3DERs) and three-dimensional biofilm electrode reactors (3DBERs) for coking wastewater treatment. Bioresour Technol. 2019;284:222-230.

51. Komorowska-Kaufman M, Majcherek H, Klaczyński E. Factors affecting the biological nitrogen removal from wastewater. Process Biochem. 2006;41:1015-1021.

52. Park JY, Yoo YJ. Biological nitrate removal in industrial wastewater treatment: which electron donor we can choose. Appl. Microbiol. Biotechnol. 2009;82:415-429.

53. Hao R, Meng C, Li J. An integrated process of three-dimensional biofilm-electrode with sulfur autotrophic denitrification (3DBER-SAD) for wastewater reclamation. Appl. Microbiol. Biotechnol. 2016;100:7339-7348.

54. He Y, Wang Y, Song X. High-effective denitrification of low $\mathrm{C} / \mathrm{N}$ wastewater by combined constructed wetland and biofilm-electrode reactor (CW-BER). Bioresour. Technol. 2016;203:245-251.

55. Tong S, Chen N, Wang H, et al. Optimization of C/N and current density in a heterotrophic/biofilm-electrode autotrophic denitrification reactor (HAD-BER). Bioresour. Technol. 2014;171: 389-395.

56. Liu Y, Gan L, Chen Z, megharaj M, naidu R. Removal of nitrate using Paracoccus sp. YF1 immobilized on bamboo carbon. J. Hazard. Mater. 2012;229:419-425.

57. Wang R-C, Wen X.-H, Quin Y. Influence of carrier concentration on the performance and microbial characteristics of a suspended carrier biofilm reactor. Process Biochem. 2005;40:2992-3001.

58. Park HI, Kim JS, Kim DK, Choi YJ, Pak DW. Nitrate-reducing bacterial community in a biofilm-electrode reactor. Enzyme. Microb. Technol. 2006;39:453-458.

59. Xiao B, Luo M, Wang X, et al. Electricity production and sludge reduction by integrating microbial fuel cells in anoxic-oxic process. Waste Manage. 2017;69:346-352.

60. Lin C, Gan L, Chen ZL. Biodegradation of naphthalene by strain 
Bacillus fusiformis (BFN). J. Hazard. Mater. 2010;182:771-777.

61. Feng Su J, Cheng C, Huang T, Wei L. Performance of the dominant bacterial species and microbial community in autotrophic denitrification coupled with iron cycle in immobilized systems. Mar. Pollut. Bull. 2017;117:88-97.

62. Vasiliadou I, Pavlou S, Vayenas DV. A kinetic study of hydrogenotrophic denitrification. Process Biochem. 2006;41:1401-1408.

63. van Kessel MAHJ, Speth DR, Albertsen M, et al. Complete nitrification by a single microorganism. Nature 2015;528:555-559.

64. Ji B, Wang H, Yan K. Nitrate and COD removal in an upflow biofilter under an aerobic atmosphere. Bioresour. Technol. 2014;158:156-160.

65. Wang X, Wen X, Yan H, Ding K, Zhao F, Hu M. Bacterial community dynamics in a functionally stable pilot-scale wastewater treatment plant. Bioresour. Technol. 2011;102:2352-2357.

66. Langlois K, Gobler CJ, Walker HW, Collier JL. Microbial communities in partially and fully treated effluent of three nitrogen-removing biofilters. J. Sust. Built Environ. 2020;6:04020010.

67. Du S, Ya T, Zhang M, et al. Distinct microbial communities and their networks in an anammox coupled with sulfur autotrophic/mixotrophic denitrification system. Environ. Pollut. 2020:114190.

68. He S, Wang YM, Li CS, Li YC, Zhou J. The nitrogen removal performance and microbial communities in a two-stage deep sequencing constructed wetland for advanced treatment of secondary effluent. Bioresour. Technol. 2018;248:82-88.

69. Wang Y, Zhang Z, Ling Q, et al. Effect of temperature downshifts on biological nitrogen removal and community structure of a lab-scale aerobic denitrification process. Biochem. Eng. J. 2015;101:200-208.

70. Guo F, Liu H. Impact of heterotrophic denitrification on BOD detection of the nitrate-containing wastewater using microbial fuel cell-based biosensors. Chem. Eng. J. 2020;394:125042.

71. Yang C, Feng C, Chen N, Deng Y, Hu W, Xue L. Development of a novel palm fiber biofilm electrode reactor (PBER) for nitrate-contaminated wastewater treatment: performance and mechanism. Environ. Sci. Water Res. Technol. 2020;6:839-850. 